\title{
The Baby's Rights in Exclusive Breastfeeding By Family in Suburban Areas
}

\author{
Ida Yustina ${ }^{1}$, Fadilah Aini ${ }^{2}$ \\ ${ }^{1}$ Department of Health Policy and Administration, University of Sumatera Utara, Indonesia \\ idayusteyahoo.com \\ ${ }^{2}$ Student of Doctoral Program Development Studies, University of Sumatera Utara, Indonesia \\ fadillah.aini@gmail.com
}

\begin{abstract}
In Indonesia, exclusive breastfeeding is a baby's right guaranteed and legal position by enactment No. 36 about health, particularly in subsection 128 paragraph (1) which states that each baby is entitled to exclusive breastfeeding from birth to six (6) months, unless medically indicated. But in reality, the fulfillment of this right is far from expected, considering the basic health research (Riskesdas) 2013 nationally noted the achievement of exclusive breastfeeding was $30.2 \%$ (target $80 \%$ ). This indicates that such a policy has not been done effectively. Research has been done on a family in the suburban area of Medan City in Indonesia in $\mathbf{2 0 1 6}$ with the intention to analyze the fulfillment of the baby's rights in exclusive breastfeeding by family and the factors that influenced it. The data were obtained by using a questionnaire to the 80 families that had 6-12 months old children, and in-depth interviews was done to a midwife from health center. The results showed that the baby's rights in giving exclusive breastfeeding have not been fulfilled well by the family, although the mother did not work outside of the houses. It is required significant efforts from stakeholders to fulfill that baby's rights. The government should evaluate the implementation of the policy on the right of baby for being breastfed exclusively, because one of the inhibiting factor that there is no regulation in Indonesia to prohibit giving the formula milk to baby under 6 months old.
\end{abstract}

Keywords - Exclusive Breastfeeding, Family in Sub Urban

\section{INTRODUCTION}

Breast milk is the first immunization for a baby and an effective life savior which does not need high cost. It contains colostrum which is rich of antibody because it contains protein for body resistance and bacterium killer so that breastfeeding can decrease the risk for infant mortality.

A baby has the right to get exclusive breastfeeding. The World Health Organization (WHO) has recommended that gold standard in giving food to a baby is by breastfeeding it exclusively since it is born until it is six month old, preceded by Early Breastfeeding Initiation immediately after it is born. By six months old, the baby is given Food Supplement besides breastfeeding and followed by breastfeeding until it is two years old [1].

In Indonesia, as $80 \%$ of the target of exclusive breastfeeding has been achieved. However, the results of some surveys have found that the achievement is still far from what is targeted. The result of the survey of the Indonesian Health Demography revealed that it was only $32 \%$ in 2007 , $42 \%$ in $2012,54.3 \%$ in 2013, and $55.7 \%$ in 2015 [2]. This achievement is far from what has been achieved by Malaysia (90\%).

In order to guarantee the right of a baby in getting exclusive breastfeeding, Article 128, paragraph (1) of Indonesia Law No. 36/2009 on Health states that every baby has the right to get exclusive breastfeeding from its mother since it is born until it is 6 (six) months old unless there is medical indication; paragraph (2) of the same Law states that during the exclusive breastfeeding, family members, central government, local government, and community should completely support the mother by providing specific time and facility, and paragraph (3) states that specific facility should be provided at work places and at public places. Article 129 paragraph (1) states that the Government is responsible to make a policy to guarantee the right of a baby to get exclusive breastfeeding from its mother [3]. In order to realize Article 129 the Government issues the Government Regulation No. 33/2012 on Exclusive Breastfeeding. In Articles 6 and 7 of this Government Regulation, it is stated that every woman who gives birth has to breastfeed her baby with exclusive breast milk unless 1) there is medical indication, 2) there is no woman who breastfeeds the baby, and 3) the baby is separated from its mother [4]. 
In reality, however, the fulfillment of this right is far from what has been expected. It can be seen from Indonesia Basic Health Research in 2013 [5] which nationally recorded the achievement of exclusive breastfeeding of only $30.2 \%$ (from the target of $80 \%$ ). It indicates that the policy is not effective. The results of some studies indicate that exclusive breastfeeding in Indonesia is still low; there have been more women who do not do it due to many factors, such as the lack of encouragement from family members and even from health care providers.

Concerning this problem, a study was conducted in 2016 to analyze the fulfillment of the right of a baby in getting exclusive breast milk from its mother by families in the suburban areas of Medan City in Indonesia. The low coverage of exclusive breastfeeding in the suburban areas of Medan City is in Medan Deli Sub-district (29.4\%), in Medan Labuhan Sub-district (24.8\%), in Medan Marelan Sub-district (24.6\%), and in Medan Belawan Subdistrict $(24.7 \%)$. Most of the people in these areas are fishermen and factory workers [6]. Suburban is a settlement area which is located in edge of city [7].

\section{MATERIALS AND METHOD}

The research used mixed methods with concurrent triangulation design [8] by conducting quantitative and qualitative design equally. It was conducted in the suburban area of Medan City in 2016. Quantitative data were gathered by distributing questionnaires to 80 families that had 6-12 monthold children, while qualitative data were gathered by conducting in-depth interviews with selected families and midwives in health centers.

\section{RESULT}

The result of the study showed that the right of a baby in getting exclusive breastfeeding which had been surveyed was not fulfilled well. The 80 families which had been surveyed did not breastfeed their babies with exclusive breast milk which had been breastfed since the baby was born until it was 6 months old without adding and/or changing it with other food supplements (except medicines, vitamins, and mineral). It indicated that the babies' right to get exclusive breastfeeding was not fulfilled. The families also did not know that exclusive breastfeeding was the right of a baby as it was stipulated in Law No. 36/2009; they also did not know about the sanction which could be imposed on those who did not breastfeed their babies exclusively.

The midwives who had been interviewed said that the achievement of exclusive breastfeeding was very low. They admitted that early initiation of breastfeeding was closely related to exclusive breastfeeding, especially in giving colostrum which was very beneficial for a baby's body. However, it was not carried out even though the Government Regulation No. 33/2012 on Exclusive Breastfeeding requires health care providers to ask a childbirth woman to carry out early initiation of breastfeeding to her new born baby at least 1 (one) hour since it is born.

The families who live in the suburban areas have low social and economic status. Therefore, some factors which cause them not to breastfeed their babies exclusively are as follows: 1) they feel that the babies will get easily hungry if they are breastfed with only exclusive breast milk, 2) breast milk does not excreted, 3) the babies do not want to suck because since they are born they are given breast milk substitute by childbirth aides.

Even though the mother in this area most of them do not work outside of the houses and are assumed to have a lot of time to breastfeed their babies, in reality they do not breastfeed their babies with exclusive breastmilk. Health care providers who are expected to encourage the mother to breastfeed their babies exclusively do not do health promotion significantly in giving information about the right of a baby in getting exclusive breastfeeding according to law. Midwives as health care providers do not socialize breast care for pregnant mother so that they do not have any motivation to breastfeed their babies exclusively.

\section{DISCUSSION}

The right for health is one of human rights which has been recognized and regulated in various national and international instruments. Concerning human rights, the Government is fully responsible for fulfilling, protecting, and maintaining the right for health for the sake of its citizens' welfare. The importance of health internationally is indicated by 
the Declaration of the United Nations on November 10, 1948 in Article 25, paragraph (1) which states that "Every person shall have the right for adequate life standard, either for himself or for his family that includes important food, dwelling, clothing, health care, and social care." In the Fourth Amendment of the 1945 Constitution of the Republic of Indonesia, Article $28 \mathrm{H}$, paragraph (1), also states that "Every person shall have the right to live in physical and spiritual prosperity, to have a home and to enjoy a good and healthy environment, and shall have the right to obtain medical care." Article 9 paragraph (3) of Law No. 39/1999 on Human Rights states that every person shll have the right for his good and healthy environment. Law No. 36/2009 on Health confirms it by stating that every person has the same right in obtaining optimal health standard. Therefore, fulfilling the right for health becomes the responsibility of the Government toward its citizens.

In Law No. 36/2009, it is stated that exclusive breastfeeding is the right of a baby. Article 20 of the Law even states that "Each person who intentionally hampers exclusive breastfeeding program as it is stipulated in Article 128, paragraph (2) will be put in prison no later than 1 (one) year and fined not more than IDR 100 million."

The commitment of mainstreaming exclusive breastfeeding from the policy point of view is stated explicitly by the Government of the Republic of Indonesia. However, in the community its implementation does not run well. The indicator is that the exclusive breastfeeding done by the breastfeeding women, including the samples of this study, is low. The main inhibiting factor of the policy is the weakness of the Government as the representation of the State in carrying out the policy. The facility needed for implementing the policy is not adequate such as the absence of the clear mechanism about the way to implement the sanction when Article 128, paragraph (2) was not implemented. The theory of implementation by George C. Edwards III [9] says that the implementation of a policy is influenced by some variables: bureaucratic structure, disposition, communication, and resources. These variables are correlated with one another. Meter and Horn in Winarno [10] says that variable which has influence in implementing policy, besides communication as well, the characteristics of implementors, economic, social and politic condition.

The result of some studies indicate that in the level of family, exclusive breastfeeding which is not done by a mother is caused by some factors: lack of knowledge about the benefit of exclusive breastfeeding, lack of motivation of a mother to breastfeed her baby, lack of husband's support, people's habit which has been crystallized to be a culture in giving food supplement to a baby below 6 months old by the belief that the baby will be a good adult in the future, the mother works outside of the house, lack of breastmilk, an assumption that a baby will be hungry if it is not given food supplement, and health care providers' encouragement to motivate mother to breastfeed their babies is still low [11].

The results of some studies on the implementation of early initiation of breastfeeding which is required by the Government Regulation No. 33/2012 on Exclusive Breastfeeding show that health care providers like midwives who help mother give birth to babies tend not to carry out early initiation of breastfeeding; instead, they stimulate the mother to give their babies formula milk to their unrecommended aged-babies (below 6 months old) [12]. Some reasons why the midwives do not carry out early initiation of breastfeeding are as follows: 1) the limitation of resources; in this case, there is only one midwife who helps childbirths while early initiation of breastfeeding needs more aides, 2) It takes a long time while the asides have to do other jobs, and 3) there is no regulation to prohibit giving formula milk to babies by health care providers has caused midwives to be the "agents" of formula milk, let alone formula milk producers give them incentives for this job. This condition is far different from what the Malaysian Government does with its policy which prohibits hospitals and especially health care providers to provide formula milk. Pregnant mother in Malaysia is conditioned to breastfeed their babies with exclusive breast milk according the existed policy. The Indonesia government should evaluate the implementation of the policy on the right of baby for being breastfed exclusively, to find out the factors which make the policy is not work. However, without the implementation of sanctions as mentioned in the regulation, the policy become only papers. 


\section{CONCLUSION}

1. The policy on the right of a baby for being breastfed exclusively according to Indonesia Law No. 36/2009 on Health is not fulfilled properly by the families in the suburban areas of Medan City.

2. The inhibiting factors of fulfilling the right of a baby for exclusive breastfeeding in this research are as follows: 1) The knowledge of mother and family members in exclusive breastfeeding and their knowledge of the right of a baby for exclusive breastfeeding are still low, 2) the health care providers do not significantly motivate mother to breastfeed their babies exclusively by not carrying out early initiation of breastfeeding and even selling formula milk to the mother, 3) communication between health care providers and families and the community in carrying out Exclusive Breastfeeding has not emphasized on the importance of exclusive breastfeeding in babies, 4) there is no regulation to prohibit giving the formula milk to baby under 6 months old.

\section{REFERENCES}

[1] Kementerian Kesehatan RI, 2014. Profil Kesehatan Indonesia tahun 2013. Jakarta.

[2] Kementerian Kesehatan RI, 2015. Profil Kesehatan Indonesia 2015.

[3] Undang-Undang Kesehatan RI No. 36 Tahun 2009

[4] Peraturan Pemerintah No. 33 Tahun 2012 tentang Pemberian Air Susu Ibu Eksklusif.

[5] Riset Kesehatan Dasar 2013. Jakarta: Kementerian Kesehatan RI; 2014.

[6] Profil Kesehatan Kota Medan, 2015

[7] Sugiyono. Metode Penelitian Kuantitatif, Kualitatif dan Kombinasi (Mixed Methods). 2014. Bandung: Alfabeta

[8] Frumkin, Howard. 2002. Urban Sprawl and Public Health. Public Health Report, May-June 2002, Volume 117: 201-217

[9] Nugroho R. Public Policy: Formulasi, Implementasi, Evaluasi dan Revisi dalam Kebijakan Publik. 2008. Jakarta: PT. Elex Media Komputindo.

[10] Budi Winarno. Kebijakan Publik: Teori dan Proses. 2007. Yogyakarta: Media Pressindo.

[11] Yustina, Ida. 2016. Rural Family's Behavior in Choosing Delivery at Home (Case at Langkat District in Province of North Sumatera). Proceeding in Indonesia Public Health Association Seminar XIII in Makassar.

[12] Sitanggang, Heddy, Ida Yustina. 2016. The Implementation of the Government Rule No. 33 on Exclusive Breastfeeding in Deli Serdang District. Prosiding in Graduate Forum in Health Systems and Policy conducted by University of Gadjah Mada Yogyakarta. 